\title{
Rasio Lingkar Pinggang-Pinggul dan Kaitannya dengan Kadar Kolesterol Total pada Wanita Dewasa
}

\author{
Susi Nurohmi ${ }^{1}$, Nurul Marfu'ah ${ }^{2}$, Mira Dian Naufalina1, Siti Awalisanah \\ Hani Farhana ${ }^{1}$, Muhammad E1 Riza ${ }^{3}$ \\ ${ }^{1}$ Program Studi Ilmu Gizi, Universitas Darussalam Gontor, Ponorogo, Indonesia \\ ${ }^{2}$ Program Studi Farmasi, Universitas Darussalam Gontor, Ponorogo, Indonesia \\ ${ }^{3}$ UPT Puskesmas Mantingan, Ngawi, 63257, Indonesia \\ email: nurohmi.susi@gmail.com
}

\begin{abstract}
This study aimed to analyze the association between anthropometric assessments and total cholesterol levels among adult women. The research design was cross sectional study with purposive sampling methode involving 92 adult women in Sambirejo village, Mantingan, Ngawi, East Java. Anthropometric assessments consisted of BMI, waist circumference, and waist-hip ratio. Data analysis consisted of univariate and bivariate using Pearson Product Moment. Bivariate analysis was performed by the correlation of anthropometric assessment with total cholesterol levels. The results showed that $15.2 \%$ subjects were overweight and $54.1 \%$ subjects had obesity. There were $80,4 \%$ subjects had waist circumference $>80 \mathrm{~cm}$ and $71,7 \%$ subjects had waist-hip ratio $\geq 0,85$. Subjects with cholesterol levels $>200 \mathrm{mg} / \mathrm{dL}$ were $31,5 \%$. The BMI and waist circumference had no correlation to total cholesterol level. The waist-hip ratio had a significant correlation to cholesterol level. The conclusion of this study was waist-hip ratio in women related to high total cholesterol level.
\end{abstract}

Keyword: Cholesterol, waist circumference, abdominal obesity

\section{Abstrak}

Penelitian ini bertujuan menganalisis hubungan penilaian antropometri dengan kadar kolesterol total pada wanita dewasa. Desain penelitian adalah studi potong lintang dengan melibatkan sebanyak 92 orang wanita dewasa. Sampel dipilih secara purposive sampling di desa Sambirejo Kecamatan Mantingan Kabupaten Ngawi Jawa Timur. Penilaian antropometri yang dilakukan meliputi IMT, lingkar pinggang dan rasio lingkar pinggang-pinggul. Analisis data terdiri atas univariat dan bivariat melalui uji Pearson Product Moment untuk melihat korelasi hasil penilaian antropometri dengan kadar kolesterol total. Hasil penelitian menunjukkan bahwa 15,2\% dan $54,1 \%$ subjek memiliki status gizi lebih dan obesitas. Sebanyak 80,4 \% memiliki lingkar pinggang $>80 \mathrm{~cm}$ dan sebanyak $71,7 \%$ memiliki rasio lingkar pinggang dan pinggul $\geq 0,85$. Subjek dengan kadar kolesterol $>200 \mathrm{mg} / \mathrm{dL}$ sebanyak $31,5 \%$. Hasil penelitian menunjukkan bahwa IMT dan lingkar pinggang tidak berkaitan dengan kadar kolesterol total. Rasio lingkar pinggang-pinggul berhubungan signifikan ( $p$ value $=0,29 ; \mathrm{r}=0,227)$ dengan kadar kolesterol. Kesimpulan dari penelitian ini adalah rasio lingkar pinggang-pinggul pada wanita berkaitan dengan tingginya kadar kolesterol total.

Kata Kunci: Kolesterol, lingkar pinggang, obesitas abdominal 


\section{PENDAHULUAN}

Penyakit tidak menular berkontribusi besar pada kasus kematian di dunia. Sebanyak 6 dari 10 penyakit yang paling banyak menyebabkan kematian adalah penyakit tidak menular. Diantara penyakit tersebut adalah penyakit jantung, stroke, dan diabetes mellitus (WHO, 2018). Obesitas dan peningkatan Indeks Massa Tubuh berperan dalam perkembangan penyakit tidak menular di negara maju atau berkembang (Banjare \& Bhalerao, 2016; Cai et al., 2014). Di Indonesia, prevalensi obesitas dan obesitas sentral sudah mencapai angka 23,1\% dan 28\%. Kedua keadaan tersebut lebih sering terjadi pada wanita dibandingkan laki-laki (Harbuwono et al., 2018). Obesitas dilaporkan terjadi sejak usia anak dan remaja (Hardiansyah et al., 2017) dan terjadi cukup tinggi pada kelompok dewasa (Hartanti \& Mulyati, 2018), Berdasarkan hasil Riskesdas 2018, prevalensi berat badan lebih dan obesitas usia $>15$ tahun meningkat menjadi 13,6\% dan 21,8\%. Sementara itu, prevalensi obesitas sentral pada usia $>18$ tahun sebesar 31\% (Kemenkes RI, 2019).

Overweight (kegemukan) dan obesitas terjadi karena adanya peningkatan jaringan lemak atau jaringan adiposa di dalam tubuh. Proporsi simpanan lemak di daerah abdomen dan gluteofemoral berkaitan dengan kematian atau penyakit-penyakit degeneratif yang disebabkan oleh obesitas, baik pada laki-laki maupun perempuan (Goossens, 2017; Manolopoulos et al., 2010). Namun demikian, wanita memiliki pola deposit lemak yang tidak sama jika dibandingkan dengan laki-laki. Deposit lemak yang ada pada wanita lebih banyak disimpan di bagian inferior yaitu pinggul dan paha. Distribusi lemak merupakan faktor risiko yang penting dalam perkembangan sindrom metabolik dan penyakit kardiovaskular (Manolopoulos et al., 2010).

Beberapa penelitian menunjukkan bahwa obesitas atau obesitas sentral memiliki keterkaitan dengan sindrom metabolik. Sindrom metabolik ini didefinisikan sebagai abnormalitas pada proses biokimia dalam tubuh yang ditandai dengan peningkatan tekanan darah atau hipertensi, kadar kolesterol yang tinggi, dan simpanan lemak berlebih yang memicu penyakit diabetes atau penyakit-penyakit yang menyerang sistem kardiovaskular (Banjare \& Bhalerao, 2016; Frank et al., 2019; Mottillo et al., 2010). Kelebihan berat badan pada individu terutama yang terpusat pada perut (central obesity) mengindikasikan adanya penumpukan lemak visceral. Hal ini merupakan faktor risiko dari tingginya asam lemak bebas, kadar kolesterol, dan trigliserida yang beredar dalam darah (Klop et al., 2013).

Salah satu metode yang dapat digunakan untuk menilai status gizi individu adalah metode penilaian antropometri. Metode ini melibatkan pengukuran dimensi fisik dan komposisi tubuh. Pengukuran ini khususnya bermanfaat untuk mengetahui suatu keadaan tubuh dimana kemungkinan telah terjadi ketidakseimbangan energi dan protein secara kronis (Gibson, 2005). Cara yang paling umum digunakan dalam 
antropometri adalah menghitung Indeks Massa Tubuh individu dengan membandingkan berat badan $(\mathrm{kg})$ dengan kuadrat tinggi badannya $\left(\mathrm{m}^{2}\right)$. Namun, cara ini tidak dapat merefleksikan bentuk tubuh, distribusi, serta proporsi otot dan lemak tubuh, sehingga dapat menimbulkan kerancuan (Dagan et al., 2013). Seidell (2010) menyebutkan bahwa lingkar pinggang merupakan cara yang lebih akurat untuk menilai distribusi lemak tubuh. Hal ini dilihat dari hasil penelitian yang menyatakan bahwa lingkar pinggang berkaitan dengan angka kesakitan dan kematian karena obesitas abdominal.

Selain menggunakan lingkar pinggang, obesitas abdominal juga dapat diketahui dengan cara menghitung rasio lingkar pinggang dan lingkar pinggul (Ahmad et al., 2016). Terdapat beberapa penelitian yang mengaitkan antara tingginya kadar kolesterol dengan obesitas abdominal. Hasilnya mengindikasikan bahwa pada jenis kelamin, negara, atau etnis tertentu obesitas abdominal yang dinilai dengan menggunakan lingkar pinggang berkaitan dengan tingginya kolesterol. Namun demikian, pada jenis kelamin, etnis, atau negara berbeda kadar kolesterol tidak berkorelasi dengan lingkar pinggang melainkan dengan rasio lingkar pinggangpinggul (Gharipour et al., 2013; Ko et al., 2012; Park et al., 2009). Berdasarkan pada beberapa penelitian tersebut, beberapa indikator antropometri memiliki pengaruh yang berbeda terhadap kadar kolesterol. Oleh karena itu, penelitian ini bertujuan untuk mengidentifikasi status gizi wanita dewasa yang dinilai dengan beberapa metode yaitu Indeks Massa Tubuh (IMT), lingkar pinggang, dan rasio lingkar pinggang-pinggul serta keterkaitannya dengan kadar kolesterol total.

\section{METODE}

\section{Desain, Waktu, dan Tempat}

Desain penelitian ini adalah cross sectional (potong lintang) dengan metode pengambilan sampel secara purposif dikarenakan sudah ditetapkannya kriteria sampel berdasarkan tujuan penelitian. Persetujuan subjek dalam berpartisipasi dalam penelitian ditunjukkan dengan inform consent. Penelitian dilakukan pada bulan Mei-Juli 2019 bertempat di desa Sambirejo Kecamatan Mantingan, Kabupaten Ngawi, Jawa Timur.

\section{Jumlah dan Cara Pengambilan Sampel}

Populasi penelitian adalah wanita dewasa yang merupakan sasaran Pos Binaan Terpadu yang termasuk dalam cakupan wilayah kerja Puskesmas Mantingan Kabupaten Ngawi. Jumlah sampel/subjek penelitian dihitung berdasarkan rumus estimasi proporsi Sastroasmoro \& Ismael (2008) sebagai berikut : 


$$
n=\frac{z_{1-\alpha / 2}^{2} p(1-p)}{d}
$$

Jumlah minimal subjek yang harus dipenuhi adalah 84 orang dengan estimasi drop out sebesar 10\%, sehingga jumlah keseluruhan subjek yang berpartisipasi adalah 92 orang. Kriteria inklusi pada penelitian ini adalah wanita dewasa usia 20-59 tahun dan bersedia berpartisipasi dalam penelitian. Kriteria eksklusi meliputi sedang dalam pengobatan, kondisi hamil, dan mengalami edema di sekitar perut. Penelitian ini sudah memenuhi izin etik dengan nomor 963/III/HREC/2019 yang dikeluarkan oleh Komisi Etik Penelitian Kesehatan RSUD Dr. Moewardi Fakultas Kedokteran Universitas Sebelas Maret.

\section{Jenis dan Cara Pengambilan Data}

Variabel yang diukur dalam penelitian ini adalah Indeks Massa Tubuh (IMT), lingkar pinggang, rasio lingkar pinggang-pinggul, dan kadar kolesterol total. Sebelum menghitung IMT, dilakukan penimbangan berat badan dengan menggunakan timbangan digital. Tinggi badan diukur menggunakan microtoise dengan ketelitian 0,1 cm. Lingkar pinggang dan pinggul diukur menggunakan metline. Penyajian sebaran data variabel IMT diklasifikasikan berdasarkan WHO Asia dengan kategori $<18,5 \mathrm{~kg} / \mathrm{m}^{2}$ gizi kurang, 18,5-22,9 kg/m² normal, 23-24,9 $\mathrm{kg} / \mathrm{m}^{2}$ overweight, $25-29,9 \mathrm{~kg} / \mathrm{m}^{2}$ obese I, dan $\geq 30 \mathrm{~kg} / \mathrm{m}^{2}$ obese II (WHO, 2004).

Penilaian lingkar pinggang diklasifikasikan menjadi dua kategori yaitu $<80 \mathrm{~cm}$ dan $\geq 80 \mathrm{~cm}$ (Anuradha, Hemachandran, \& Dutta, 2012). Rasio lingkar pinggang dan pinggul dihitung dengan membandingkan antara lingkar pinggang dan pinggul. Data ini dikelompokkan menjadi dua kategori yaitu $<0,85$ dan $\geq 0,85$ (WHO, 2011). Kadar kolesterol subjek ditentukan dengan mengambil darah kapiler pada ujung jari ketiga atau keempat dengan arah tegak lurus (Gandasoebrata, 2010). Subjek dipuasakan terlebih dahulu selama minimal 8 jam. Kadar kolesterol diklasifikasikan ke dalam dua kategori yaitu $\leq 200 \mathrm{mg} / \mathrm{dL}$ dan $>200 \mathrm{mg} / \mathrm{dL}$ (PERKI, 2017).

\section{Analisis Data}

Analisis data dilakukan secara deskriptif dan inferensia. Analisis deskriptif untuk mengetahui nilai rata-rata setiap variabel dan sebarannya berdasarkan klasifikasi. Analisis inferensia untuk mengetahui hubungan antara penilaian antropometri (IMT, lingkar pinggang, dan rasio lingkar pinggang-pinggul) dengan kadar kolesterol subjek. Data yang didapatkan terdistribusi normal dengan nilai signifikan lebih dari 0,05; sehingga uji hubungan yang digunakan adalah Pearson Product Moment untuk melihat kemaknaan dan kekuatan uji. 


\section{HASIL DAN PEMBAHASAN}

Rata-rata usia responden adalah 43,1 $\pm 11,7$ tahun. Penilaian antropometri yang dengan metode IMT menunjukkan bahwa rata-rata responden termasuk dalam kategori obesitas I yaitu $26,0 \pm 4,9 \mathrm{~kg} / \mathrm{m}^{2}$. Nilai rata-rata lingkar pinggang responden adalah $87,9 \pm 10,3 \mathrm{~cm}$, sedangkan perbandingan atau rasio lingkar pinggang-pinggul sebesar 0,9 $\pm 0,1$. Berdasarkan pengukuran kadar kolesterol total responden didapatkan rata-ratanya sebesar 181,7士40,6 mg/dL.

\section{Tabel 1. Karakteristik responden}

\begin{tabular}{lc}
\hline Variabel & Rata-rata \pm SD \\
\hline Usia (tahun) & $43,1 \pm 11,7$ \\
Indeks Massa Tubuh $\left(\mathrm{kg} / \mathrm{m}^{2}\right)$ & $26,0 \pm 4,9$ \\
Lingkar pinggang $(\mathrm{cm})$ & $87,9 \pm 10,3$ \\
Rasio lingkar pinggang-pinggul & $0,9 \pm 0,1$ \\
Kadar kolesterol total $(\mathrm{mg} / \mathrm{dL})$ & $181,7 \pm 40,6$ \\
\hline
\end{tabular}

Lingkar pinggang maupun rasio lingkar pinggang-pinggul termasuk dalam indikator obesitas sentral yang menjadi faktor risiko penyakit degeneratif. Risiko ini meningkat seiring dengan bertambahnya usia. Hal ini dapat disebabkan oleh akumulasi kerusakan atau penurunan fungsi-fungsi tubuh yang mengarah pada penyimpangan biologis tubuh termasuk terganggunya homeostasis dan fungsi metabolik (Luu \& Palczewski, 2018). Bahkan saat ini, berkembangnya penyakit degeneratif seperti hiperkolesterolemia, diabetes melitus, dan jantung koroner telah mengalami pergeseran, bukan hanya di kalangan lansia saja tetapi juga kalangan dewasa (Rubin \& Borden, 2012). Terdapat beberapa faktor risiko yang dapat memperparah perkembangan penyakit ini, salah satunya adalah gaya hidup yang kurang sehat. Adapun gaya hidup yang kurang sehat meliputi kebiasaan merokok (Konishi et al., 2014), rendahnya aktivitas fisik, serta pola makan tinggi lemak dan rendah serat (Yoeantafara \& Martini, 2017). Maharani et al. (2018) dalam penelitiannya juga menyebutkan bahwa tingginya kolesterol dalam darah dipengaruhi oleh aktivitas fisik, asupan serat serta asupan kolesterol.

Obesitas dapat terjadi karena beberapa faktor. Kejadian obesitas salah satunya dipengaruhi oleh tingkat pengetahuan gizi seseorang. Rendahnya tingkat pengetahuan gizi meningkatkan risiko obesitas pada seseorang (Nova \& Yanti, 2017). Selain itu, rendahnya aktivitas fisik dan pola makan yang buruk dapat mengarahkan seorang mengalami keseimbangan energi yang positif dimana jumlah energi yang digunakan lebih rendah dan tidak sebanding dengan energi yang masuk dalam tubuh. Jika keadaan ini terus-menerus terjadi maka dapat berakibat pada status gizi overweight, bahkan obesitas. Overweight dan obesitas didefinisikan sebagai keadaan dimana terjadi kelebihan lemak dalam tubuh. Hal ini ditunjukkan dengan 
tingginya IMT yang melebihi batas normal. Berbeda dengan cut off point status gizi yang berlaku secara umum dari WHO, masyarakat Asia memiliki nilai ambang batas status gizi normal yang lebih rendah yakni hanya pada rentang 18,5-22,9 $\mathrm{kg} / \mathrm{m}^{2}$. Oleh karena itu, wanita Asia usia dewasa dengan IMT 23-24,9 kg/m² sudah termasuk kategori overweight sementara lebih dari $25 \mathrm{~kg} / \mathrm{m}^{2}$ dikategorikan sebagai obesitas (WHO, 2004).

Berdasarkan penilaian IMT pada Tabel 2, sebagian besar responden yang berpartisipasi dalam penelitian memiliki status gizi lebih dengan kategori overweight, obesitas I, dan obesitas II. Status gizi obesitas I memiliki persentase terbanyak yaitu $33,7 \%$, diikuti obesitas II (20,7\%), dan overweight (15,2\%). Responden yang memiliki status gizi normal sebanyak 26,1\%, sedangkan 4,3\% dari keseluruhan responden termasuk dalam kategori gizi kurang. Sebagian besar responden $(75,0 \%)$ memiliki lingkar pinggang $>80 \mathrm{~cm}$ dan sebesar 68,5\% memiliki rasio lingkar pinggang-pinggul $\geq 0,85$. Terdapat $31,5 \%$ responden yang memiliki kadar kolesterol $>200 \mathrm{mg} / \mathrm{dL}$.

Tabel 2. Sebaran responden berdasarkan karakteristik

\begin{tabular}{lcc}
\hline Variabel & $\mathbf{n}$ & $\mathbf{\%}$ \\
\hline Indeks Massa Tubuh $\left(\mathrm{kg} / \mathrm{m}^{2}\right)$ & & \\
$\quad$ Kurang & 4 & 4,3 \\
$\quad$ Normal & 24 & 26,1 \\
$\quad$ Overveight & 14 & 15,2 \\
$\quad$ Obesitas I & 31 & 33,7 \\
$\quad$ Obesitas II & 19 & 20,7 \\
Lingkar pinggang $(\mathrm{cm})$ & & \\
$\quad<80$ & 18 & 19,6 \\
$\quad \geq 80$ & 74 & 80,4 \\
Rasio lingkar pinggang-pinggul & & \\
$\quad<0,85$ & 26 & 28,3 \\
$\quad \geq 0,85$ & 66 & 71,7 \\
Kadar kolesterol total (mg/dL) & & \\
$\quad \leq 200$ & 63 & 68,5 \\
$\quad>200$ & 29 & 31,5 \\
\hline
\end{tabular}

Sebagian besar wanita dewasa dalam penelitian ini memiliki IMT lebih dari 23 $\mathrm{kg} / \mathrm{m}^{2}$. Selain itu lebih dari setengah responden mengalami obesitas abdominal yang ditandai dengan tingginya lingkar pinggang $(\geq 80 \mathrm{~cm})$ dan rasio lingkar pinggangpinggul $(\geq 0,85)$. Hal ini menandakan adanya tumpukan lemak dalam tubuh. Pada usia dewasa tubuh memang cenderung akan mengalami perubahan distribusi lemak dan otot yang berakibat pada bertambahnya massa lemak dan berkurangnya massa otot (St-Onge \& Gallagher, 2010). Deposit atau simpanan lemak tersebut dapat diklasifikasikan sebagai lemak subkutan dan lemak visceral. Lemak subkutan 
merupakan simpanan lemak yang terletak dalam lapisan kulit sedangkan lemak visceral adalah simpanan lemak yang terdapat dalam rongga abdomen dan berada di antara organ-organ internal. Lemak visceral pada laki-laki paling tidak menyumbang sebesar 10-20\% dari simpanan lemak tubuh, sedangkan perempuan hanya berkisar antara 5-8\% (Ibrahim, 2010).

Lemak yang terdistribusi pada bagian atas tubuh sebagian besar berkaitan dengan peningkatan lemak visceral yang pada akhirnya dapat menyebabkan gangguan metabolisme tubuh pada individu dengan status gizi overveight atau obesitas. Obesitas sentral atau abdominal merupakan salah satu indikasi terjadinya penumpukan lemak visceral dalam tubuh yang merupakan faktor risiko dari dislipidemia (Jensen, 2008). Wanita memiliki lebih banyak lemak tubuh dibandingkan laki-laki, tetapi kelebihan lemak pada wanita memiliki konsekuensi yang berbeda dengan laki-laki dalam hal kerusakan metabolik dalam tubuh. Kelebihan lemak pada wanita yang cenderung terdistribusi di bagian bawah (pear shape) dibandingkan laki-laki yang lebih banyak terdistribusi di daerah abdomen (apple shape) berkaitan dengan berkurangnya risiko penyakit kardiometabolik (Karastergiou et al., 2012). Oleh karena Lemak pada wanita lebih banyak tersimpan sebagai lemak subkutan sementara laki-laki terutama sebagai lemak visceral (Fuente-Martín et al., 2013), penting untuk melakukan penilaian obesitas pada wanita dengan mempertimbangkan simpanan lemak yang berada di tubuh bagian bawah.

Perbedaan distribusi lemak ini salah satunya dipengaruhi oleh keberadaan hormon seks yang berbeda pada laki-laki dan perempuan (Frank et al., 2019). Hormon-hormon yang ada dalam tubuh bertugas untuk mengintegrasikan interaksiinteraksi metabolik pada organ-organ dalam tubuh yang penting untuk bisa menjalankan fungsinya seperti reproduksi dan juga fungsi-fungsi metabolik lain. Hormon steroid berperan dalam pengaturan metabolisme adiposity dan juga mempengaruhi pengaturan spesifik pada simpanan lemak (Dunford \& Riddell, 2016). Pada manusia, faktor-faktor yang dapat mengontrol distribusi lemak salah satunya ditentukan oleh konsentrasi hormon seks. Laki-laki rata-rata memiliki persentase lemak total yang lebih rendah, tetapi persentase lemak abdominalnya tinggi sedangkan perempuan justru memiliki persentase lemak total yang lebih besar dibandingkan dengan laki-laki dan lebih cenderung disimpan sebagai lemak subkutan. Sementara itu berat badan dan distribusi lemak abdomen berbeda pada wanita usia produktif dan menopause. Penurunan sekresi esterogen pada wanita menopause berkaitan dengan berkurangnya simpanan lemak subkutan dan meningkatnya simpanan lemak abdomen (Lizcano \& Guzmán, 2014).

Wiklund et al. (2008) dalam penelitiannya menjelaskan bahwa keberadaan lemak abdomen pada laki-laki maupun wanita memiliki korelasi yang positif terhadap kadar kolesterol dan trigliserida di dalam darah. Namun, keberadaan lemak gynoid (lemak yang tersimpan pada tubuh bagian bawah) dapat menurunkan risiko 
terhadap gejala gangguan metabolisme lipid atau dislipidemia (Reddy \& Nambiar, 2018). Sel-sel adiposa pada dasarnya merupakan komponen jaringan yang merupakan kumpulan dari trigliserida sebagai sumber energi bagi tubuh jika dibutuhkan. Pada metabolisme yang normal, sel adiposa ini dapat dengan mudah menyerap dan menyimpan asam lemak bebas dan trigliserida selama masa posprandial. Jika seseorang memiliki asupan energi dan lemak yang berlebih secara terus-menerus, maka simpanan lemak dalam jaringan ini akan berlebih dan dapat mengakibatkan resistensi insulin (Ibrahim, 2010).

Analisis bivariat yang dilakukan pada variabel IMT, lingkar pinggang, rasio lingkar pinggang-pinggul, dan kadar kolesterol dijelaskan dalam Tabel 3. Dari hasil analisis variabel kadar kolesterol dengan IMT didapatkan hasil p-value $>0,05$. Demikian juga pada variabel lingkar pinggang, nilai $p$-value yang didapatkan $>0,05$. Namun, berdasarkan uji korelasi antara variabel kadar kolesterol total dengan rasio lingkar pingang-pinggul didapatkan p-value <0,05. Dengan demikian, dapat disimpulkan bahwa terdapat hubungan antara rasio lingkar pinggang-pinggul dengan kadar kolesterol total. Koefisien korelasi yang bernilai positif $(0,227)$ menunjukkan bahwa semakin besar rasio lingkar pinggang-pinggul, semakin tinggi kadar kolesterol total.

Tabel 3. Hubungan penilaian antropometri dengan kadar kolesterol total

\begin{tabular}{lcc}
\hline Variabel & r & p-value \\
\hline Indeks Massa Tubuh $\left(\mathrm{kg} / \mathrm{m}^{2}\right)$ & 0,030 & 0,779 \\
Lingkar pinggang $(\mathrm{cm})$ & 0,150 & 0,153 \\
Rasio lingkar pinggang-pinggul & 0,227 & $0,029^{*}$ \\
\hline
\end{tabular}

*) Signifikan pada $\alpha<0,05$

Hasil uji statistik menunjukkan bahwa tidak terdapat korelasi antara kadar kolesterol total dengan indikator IMT dan lingkar pinggang pada wanita dewasa. Namun demilikian, kadar kolesterol berkorelasi positif dengan rasio lingkar pinggang-pinggul. Berdasarkan penelitian yang dilakukan oleh Faeh et al. (2012), nilai IMT yang semakin tinggi meningkatkan risiko tingginya kadar kolesterol pada penderita penyakit kardiovaskuler. Hal serupa dijelaskan oleh Christian et al. (2009) bahwa lingkar pinggang dan IMT perlu diperhatikan karena berkaitan dengan perubahan profil lipid. Hussain et al. (2019) dalam penelitiannya menyebutkan bahwa kadar kolesterol total justru lebih tinggi pada subjek dengan status gizi normal dibandingkan subjek overweight dan obesitas. Hal ini menunjukkan bahwa status gizi yang dinilai menggunakan IMT secara umum belum bisa menggambarkan distribusi lemak tubuh.

Rasio lingkar pinggang-pinggul lebih dapat digunakan sebagai indikator obesitas sentral yang mempertimbangkan distribusi lemak tubuh di daerah abdomen 
dan gluteofemoral. Distribusi lemak pada wanita dipengaruhi oleh keberadaan hormon estrogen yang masih berperan aktif sebelum masa menopause. Estrogen dan reseptor estrogen (ER) berperan penting dalam regulasai beberapa aspek metabolisme, termasuk metabolisme glukosa dan lipid (Palmisano, Zhu, \& Stafford, 2017). Beberapa penelitian menyebutkan bahwa gangguan pensinyalan estrogen dikaitkan dengan perkembangan penyakit metabolik. Defisiensi estrogen atau menurunnya level estrogen setelah dapat memicu kelainan regulasi pada proses metabolisme. Terjadinya menopause berkaitan dengan beberapa perubahan metabolik dalam tubuh. Hal ini mengakibatkan wanita setelah menopause memiliki peluang yang sama dengan laki-laki dalam hal berkembangnya penyakit aterosklerosis dikarenakan berkurangnya fungsi reseptor esterogen alfa yang mengakibatkan gangguan metabolisme glukosa dan profil lipid dalam darah (Faulds et al., 2012).

Regulator utama keseimbangan kolesterol di dalam darah adalah sterol regulatory element-binding protein 1 dan 2 (SREBP 1 dan 2) yang bertugas mentranskripsi gen kolesterogenik seperti reseptor LDL dan HMG-CoA reduktase. Peran utamanya adalah mengikat kolesterol LDL yang bersirkulasi dalam darah dan mencegah penumpukan kolesterol di permukaan membran pembuluh darah, sehingga dapat mencegah aterosklerosis (Faulds et al., 2012). Estrogen diketahui merupakan hormon steroid yang mampu menurunkan konsentrasi kolesterol terutama LDL dan meningkatkan kolesterol HDL (Darabi et al., 2011). Hamden et al. (2011) dalam penelitiannya menyebutkan bahwa tikus diabetes yang diberikan perlakuan estrogen menunjukkan penurunan aktivitas lipase yang mampu menurunkan kolesterol total dengan konsentrasi mencapai 53\% sementara terdapat peningkatan kolesterol HDL.

\section{KESIMPULAN}

Sebagaian besar wanita dewasa yang berpartisipasi dalam penelitian ini memiliki status gizi overweight, obesitas, dan obesitas abdominal berdasarkan lingkar pinggang dan rasio lingkar pinggang-panggul. Analisis statistik yang telah dilakukan menunjukkan bahwa tidak terdapat hubungan antara penilaian status gizi dengan metode IMT dan lingkar pinggang dengan kadar kolesterol subjek. Penilaian status gizi berdasarkan rasio lingkar pinggang-pinggul menunjukkan korelasi yang signifikan dengan kadar kolesterol total. Penelitian selanjutnya perlu dilakukan dengan variabel tekanan darah, glukosa darah puasa, dan profil lipid darah yang lebih lengkap untuk mengkonfirmasi lebih lanjut mengenai pengaruh obesitas abdominal terhadap kejadian sindrom metabolik. Pemberian intervensi berupa pendidikan gizi serta monitoring perlu diakukan untuk dapat menurunkan angka status gizi lebih dan mencegah penyakit degeneratif di masyarakat. 


\section{UCAPAN TERIMA KASIH}

Penelitian ini terlaksana atas dukungan dari beberapa pihak. Oleh karena itu, penulis mengucapkan terimakasih kepada Kemenristek DIKTI yang telah memberikan bantuan dana pada proposal riset yang berjudul Pengaruh Pemberian Jus Pamelo Sebagai Produk Buah Lokal Terhadap Profil Lipid Darah Wanita Dengan Status Gizi Lebih. Ucapan terimakasih juga penulis sampaikan kepada UPT Puskesmas Mantingan, Ngawi yang telah bersedia bekerjasama dalam penelitian ini.

\section{DAFTAR PUSTAKA}

Ahmad, N., Adam, S. M., Nawi, A., Hassan, M., \& Ghazi, H. (2016). Abdominal obesity indicators: Waist circumference or waist-to-hip ratio in Malaysian adults population. International Journal of Preventive Medicine, 7(1), 82-87. https:/ / doi.org/10.4103/2008-7802.183654

Anuradha, R., Hemachandran, S., \& Dutta, R. (2012). The Waist Circumference measurement: A simple method for assessing the abdominal obesity. Journal of Clinical and Diagnostic Research, 6(9), 1510-1513. https://doi.org/10.7860/JCDR/2012/4379.2545

Banjare, J. B., \& Bhalerao, S. (2016). Obesity associated noncommunicable disease burden. International Journal of Health \& Allied Sciences, 5(2), 81-87. https://doi.org/10.4103/2278-344X.180429

Cai, L., Han, X., Qi, Z., Li, Z., Zhang, Y., Wang, P., \& Liu, A. (2014). Prevalence of overweight and obesity and weight loss practice among Beijing adults, 2011. PLOS ONE, 9(9). https://doi.org/10.1371/journal.pone.0098744

Christian, A. H., Mochari, H., \& Mosca, L. J. (2009). Waist Circumference, Body Mass Index, and Their Association With Cardiometabolic and Global Risk. J Cardiometab Syndr., 4(1), 12-19. https://doi.org/10.1111/j.15594572.2008.00029.x. Waist

Dagan, S. S., Segev, S., Novikov, I., \& Dankner, R. (2013). Waist circumference vs body mass index in association with cardiorespiratory fitness in healthy men and women: a cross sectional analysis of 403 subjects. Nutrition Journal, 12, 1-8. https://doi.org/10.1186/1475-2891-12-12

Darabi, M., Rabbani, M., Ani, M., Zarean, E., Panjehpour, M., \& Movahedian, A. (2011). Increased leukocyte ABCA1 gene expression in post-menopausal women on hormone replacement therapy. Gynecological Endocrinology. https://doi.org/10.3109/09513590.2010.507826

Dunford, E. C., \& Riddell, M. C. (2016). The metabolic implications of glucocorticoids in a high-fat diet setting and the counter-effects of exercise. Metabolites, 6(4). https://doi.org/10.3390/metabo6040044

Faeh, D., Braun, J., \& Bopp, M. (2012). Body mass index vs cholesterol in cardiovascular disease risk prediction models. Archives of Internal Medicine, 172(22), 1766-1768. https:/ / doi.org/10.1001/2013.jamainternmed.327

Faulds, M. H., Zhao, C., Dahlman-Wright, K., \& Gustafsson, J.-A. (2012). The diversity of sex steroid action: Regulation of metabolism by estrogen signaling. 
Journal of Endocrinology, 212(1), 3-12. https://doi.org/10.1530/JOE-11-0044

Frank, A. P., De Souza Santos, R., Palmer, B. F., \& Clegg, D. J. (2019). Determinants of body fat distribution in humans may provide insight about obesity-related health risks. Journal of Lipid Research, 60(10), 1710-1719. https://doi.org/10.1194/jlr.R086975

Fuente-Martín, E., Argente-Arizón, P., Ros, P., Argente, J., \& Chowen, J. A. (2013). Sex differences in adipose tissue. Adipocyte, 2(3), 128-134. https://doi.org/10.4161/adip.24075

Gandasoebrata, R. (2010). Penuntun laboratorium klinik. teori dan aplikasi kesehatan kerja. Jakarta: Dian Rakyat.

Gharipour, M., Sarrafzadegan, N., Sadeghi, M., Andalib, E., Talaie, M., Shafie, D., \& Aghababaie, E. (2013). Predictors of metabolic syndrome in the Iranian population: Waist circumference, body mass index, or waist to hip ratio? Cholesterol, 2013. https://doi.org/10.1155/2013/198384

Gibson, R. (2005). Principles of nutritional assessment. Oxford: Oxford University Press.

Goossens, G. H. (2017). The Metabolic Phenotype in Obesity: Fat Mass, Body Fat Distribution, and Adipose Tissue Function. Obesity Facts, 10(3), 207-215. https://doi.org/10.1159/000471488

Hamden, K., Jaouadi, B., Zaraî, N., Rebai, T., Carreau, S., \& Elfeki, A. (2011). Inhibitory effects of estrogens on digestive enzymes, insulin deficiency, and pancreas toxicity in diabetic rats. Journal of Physiology and Biochemistry. https://doi.org/10.1007/s13105-010-0056-0

Harbuwono, D. S., Pramono, L. A., Yunir, E., \& Subekti, I. (2018). Obesity and central obesity in Indonesia: Evidence from a national health survey. Medical Journal of Indonesia, 27(2), 114-120. https://doi.org/10.13181/mji.v27i2.1512

Hardiansyah, A., Yunianto, A. E., Laksitoresmi, D. R., \& Tanziha, I. (2017). Konsumsi Minuman Manis dan Kegemukan pada Mahasiswa. Jurnal Gizi Universitas Mubammadiyah Semarang, 6(2), 20-26.

Hartanti, D., \& Mulyati, T. (2018). Hubungan Asupan Energi, Serat, Dan Pengeluaran Energi Dengan Rasio Lingkar Pinggang-Panggul (Rlpp). NutriSains: Jurnal Giði, Pangan Dan Aplikasinya, 1(2), 46. https://doi.org/10.21580/ns.2017.1.2.2359

Hussain, A., Ali, I., Kaleem, W. A., \& Yasmeen, F. (2019). Correlation between body mass index and lipid profile in patients with type 2 diabetes attending a tertiary care hospital in Peshawar. Pakistan Journal of Medical Sciences, 35(3), $591-$ 597. https://doi.org/10.12669/pjms.35.3.7

Ibrahim, M. M. (2010). Subcutaneous and visceral adipose tissue: Structural and functional differences. Obesity Reviews, 11(1), 11-18. https://doi.org/10.1111/j.1467-789X.2009.00623.x

Jensen, M. D. (2008). Role of body fat distribution and the metabolic complications of obesity. Journal of Clinical Endocrinology and Metabolism. https://doi.org/10.1210/jc.2008-1585

Karastergiou, K., Smith, S. R., Greenberg, A. S., \& Fried, S. K. (2012). Sex differences in human adipose tissues - The biology of pear shape. Biology of Sex Differences, 3(1), 1. https://doi.org/10.1186/2042-6410-3-13 
Kemenkes RI. (2019). Laporan Nasional Hasil Riset Kesehatan Dasar (Riskesdas) Indonesia tahun 2018. Riset Kesehatan Dasar 2018, pp. 68-72.

Klop, B., Willem, J., Elte, F., \& Cabezas, M. C. (2013). Dyslipidemia in Obesity: Mechanisms and Potential Targets. Nutrients, 5, 1218-1240. https://doi.org/10.3390/nu5041218

Ko, K.-P., Oh, D.-K., Min, H., Kim, C.-S., Park, J.-K., Kim, Y., \& Kim, S. S. (2012). Prospective study of optimal obesity index cutoffs for predicting development of multiple metabolic risk factors: The Korean genome and epidemiology study. Journal of Epidemiology, 22(5), 433-439. https://doi.org/10.2188/jea.JE20110164

Konishi, H., Miyauchi, K., Kasai, T., Tsuboi, S., Ogita, M., Naito, R., ... Daida, H. (2014). Long-term prognosis and clinical characteristics of young adults $(\leq 40$ years old) who underwent percutaneous coronary intervention. Journal of Cardiology, 64(3), 171-174. https://doi.org/10.1016/j.jjcc.2013.12.005

Lizcano, F., \& Guzmán, G. (2014). Estrogen deficiency and the origin of obesity during menopause. BioMed Research International, 2014. https:/ / doi.org/10.1155/2014/757461

Luu, J., \& Palczewski, K. (2018). Human aging and disease: Lessons from agerelated macular degeneration. Proceedings of the National Academy of Sciences, 115(12), 2866-2872. https://doi.org/10.1073/pnas.1721033115

Maharani, A., Marjan, A. Q., \& Puspareni, L. D. (2018). The Relation of Fiber Intake, Cholesterol, and Physical Activity with Blood Cholesterol Level of Women Adult in Bogor Aerobic Studio. Nutri-Sains: Jurnal Giri, Pangan Dan Aplikasinya, 2(2), 1. https://doi.org/10.21580/ns.2018.2.2.2604

Manolopoulos, K. N., Karpe, F., \& Frayn, K. N. (2010). Gluteofemoral body fat as a determinant of metabolic health. International Journal of Obesity, 34(6), 949959. https://doi.org/10.1038/ijo.2009.286

Mottillo, S., Filion, K. B., Genest, J., Joseph, L., Pilote, L., Poirier, P., ... Eisenberg, M. J. (2010). The metabolic syndrome and cardiovascular risk: A systematic review and meta-analysis. Journal of the American College of Cardiology, 56(14), 1113-1132. https://doi.org/10.1016/j.jacc.2010.05.034

Nova, M., \& Yanti, R. (2017). Faktor-Faktor Yang Berhubungan Dengan Obesitas Pada Orang Dewasa Di Kota Padang Panjang. Nutri-Sains: Jurnal Gizi, Pangan Dan Aplikasinya, 1(1), 12. https://doi.org/10.21580/ns.2017.1.1.1957

Palmisano, B. T., Zhu, L., \& Stafford, J. M. (2017). Role of estrogens in the regulation of liver lipid metabolism. Advances in Experimental Medicine and Biology, 1043(615), 227-256. https://doi.org/10.1007/978-3-319-70178-3_12

Park, S.-H., Choi, S.-J., Lee, K.-S., \& Park, H.-Y. (2009). Waist circumference and waist-to-height ratio as predictors of cardiovascular disease risk in Korean adults. Circulation Journal, 73(9), 1643-1650. https://doi.org/10.1253/circj.CJ09-0161

Persatuan Dokter Spesialis Kardiovaskuler Indonesia [PERKI]. (2017). Panduan tata laksana dislipidemia. Jakarta: Perhimpunan Dokter Spesialis Kardiovaskuler Indonesia.

Reddy, R., \& Nambiar, S. (2018). No TitleCorrelation of anthropometric indices 
with lipid profile in adult females. National Journal of Physiology, Pharmacy and Pharmacology, 8(4), 512-516.

Rubin, J. B., \& Borden, W. B. (2012). Coronary heart disease in young adults. Current Atherosclerosis Reports, 14(2), 140-149. https://doi.org/10.1007/s11883-0120226-3

Sastroasmoro, S., \& Ismael, S. (2008). Dasar-dasar metodologi penelitian klinis. Jakarta: CV Sagung Seto.

Seidell, J. C. (2010). Waist circumference and waist/hip ratio in relation to all-cause mortality, cancer and sleep apnea. European Journal of Clinical Nutrition, 64(1), 35-41. https://doi.org/10.1038/ejcn.2009.71

St-Onge, M.-P., \& Gallagher, D. (2010). Body composition changes with aging: The cause or the result of alterations in metabolic rate and macronutrient oxidation? Nutrition, 26(2), 152-155. https:/ / doi.org/10.1016/j.nut.2009.07.004

WHO Expert Consultation. (2004). Appropriate body-mass index for Asian populations and its implications for policy and intervention strategies. The Lancet, 363(9403), 157-163. https://doi.org/10.1016/S0140-6736(03)15268-3

Wiklund, P., Toss, F., Weinehall, L., Hallmans, G., Franks, P. W., Nordström, A., \& Nordström, P. (2008). Abdominal and gynoid fat mass are associated with cardiovascular risk factors in men and women. Journal of Clinical Endocrinology and Metabolism, 93(11), 4360-4366. https:/ / doi.org/10.1210/jc.2008-0804

World Health Organization (WHO). (2011). Waist circumference and waist-hip ratio: Report of a WHO expert consultation Geneva, 8-11 december 2008. Geneva: WHO Press.

World Health Organization (WHO). (2018). World health statistics 2018: monitoring health for the SDGs, sustainable development goals. Geneva: License: CC BY-NC-SA 3.0 IGO.

Yoeantafara, A., \& Martini, S. (2017). Pengaruh pola makan terhadap kadar kolesterol total. Media Kesehatan Masyarakat Indonesia, 13(4), 304-309. 
Halaman ini sengaja dikosongkan. 